\title{
XIV. On a remarkable fall of hail; with observations on the probable nature of such phænomena
}

\section{P.J. Martin Esq. F.G.S.}

To cite this article: P.J. Martin Esq. F.G.S. (1840) XIV. On a remarkable fall of hail; with observations on the probable nature of such phænomena, Philosophical Magazine Series 3, 16:101, 85-87, DOI: $10.1080 / 14786444008649986$

To link to this article: http://dx.doi.org/10.1080/14786444008649986

册 Published online: 01 Jun 2009.

Submit your article to this journal

Џlll Article views: 1

Q View related articles $₫$ 
XIV. On a remarkable Fall of Hail; with Observations on the probable Nature of such Phonomena. By P. J. Martin, Esq., F.G.S.

\title{
Dear Sir,
}

\author{
To Richard Taylor, Esq.
}

NOT having met with any notice of the remarkable fall of hail which took place during the storm of thunder and lightning that passed over the counties of Sussex, Surrey, and Middlesex on the evening of the 7 th of last July, I beg leave to offer you the following memorandum respecting it, with some short observations on the probable nature of such phænomena, which, if not altogether new, may coincide with and serve to strengthen the opinions of more experienced meteorologists.

Except in the fall of very large hail, the storm above-mentioned did not differ materially from the wide-spreading and grander thunder storms which sometimes gather on our coasts, and pass over the metropolis, from the south-west, after a sultry day or two in the middle of summer, but of which we have not had any very remarkable examples for the last five or six years.

One of these storms generally rises slowly over the SouthDowns towards evening, in the form of a flimsy cirrostratus, gradually deepening as the night advances, and engendering denser cumuli as it draws inland. In general it is met by an under current of air from the north-east; but this is not invariably the case, for the under current often comes in at an acute angle with the motion of the gathering clouds, from the south or south-east; and sometimes, as in this instance, there is a dead calm below, whilst the clouds are advancing with considerable rapidity in the higher regions. I may observe, in passing, that a long-continued and steady influx of a warm north-easterly current towards the points of precipitation generally characterizes the grandest of these exhibitions; so that it is common to hear it said here that "a tempest," for so the Sussex people call such a storm, "comes up against the wind."

On the evening in question, the storm gathered on the line of coast between Selsea Bill and Beachy Head, was heavy over Brighton, and seemed to have its nucleus or central range from about Shoreham over Henfield, East Grinstead, and Croydon. On its western verge it passed over Arundel, Pulborough, Horsham, and Dorking, and was noted at Chiswick to be " accompanied with unusually little rain." The hail which I am about to describe was confined to this 
western extremity, and its ravages did not extend more than about a mile and a quarter wide, whilst in length they reached about twenty miles, viz. from Arundel to the vicinity of Horsham. Hail fell, I believe, further on, quite into Surrey, but the fall of large stones was limited to the space above mentioned. We had been watching the rise, and dissolution into the expanding body of the nimbus of many heavy cumuli from the south and south-west, with some grand explosions of thunder and lightning, when we observed a dense mass approach us in that direction from the Arundel quarter, accompanied by a rushing or rather roaring sound, clearly to be distingnished from the thunder, and attended with a pretty sharp blast of wind. In a few moments hail of the ordinary kind began to fall copiously, and this in a few moments more was intermixed with stones of an enormous size, the slapping of which could be clearly distinguished from the roaring of the mass of other hail on the slated roof of the summer-house in which I and my family had taken shelter. Very little rain fell, and the duration of the hail-storm was about ten minutes, only five of which was occupied by the fall of the largest hail-stones. On its clearing off, the ground was observed to be whitened by the hail, amongst which the large stones lay like tennis-balls amongst marbles; and on measuring some of them, after they had lain several minutes melting on the ground, we found many five, six, and seven inches in circumference. These large stones were more compact in their structure than the smaller ones, and were all of the flattened spheroidal form, and likened by many of the common people in size and shape to their thick old-fashioned watches. A dead calm succeeded to the passage of the storm, and the atmosphere continued to be encumbered with dark clouds, but without any more rain during the night.

The congelation of large drops of rain at the moment of aggregation, and the formation of ordinary hail, and even a considerable accretion of more ice to the original globule in its passage downwards, do not seem to be very difficult of comprehension and explanation. But there is only one way in which I can suppose such masses of ice as these can be suspended long enongh in the atmosphere to grow to such enormous sizes, and that is by the assistance of a nubilar whirlwind or water-spout (Trombe aërienne) with sufficient power to keep them in its whorl, and to resist the earth's attraction, whilst the concretive action is going on, till their momentum overcomes the suspending power, or till they are thrown beyond the range of its intensity. That such operations 
are amongst the reciprocal electrical phænomena of the clouds, distinct from, thongh allied to the water-spout, is, perhaps, well-known; and I was myself once witness to an appearance of this sort, between a higher and a lower cloud, that had the strongly electric aspect before they had resolved themselves into nimbus. It was a bent narrow column of dark vapour, which I could distinctly observe to be in rapid rotatory motion, passing from one cloud to the other, continuing for some minutes, and then gradually disappearing. During this time it emitted no sound, and had no visible connexion with the earth whatever.

The above theory of hail-stones will be further corroborated if we consider the form of the stones in this instance, viz. a sphere flattened at its poles, as the result of a rotatory motion; especially if it be a law, as perhaps it is, that all solids in rapid gyration acquire per seipsos a rotation on their own axes. I am, dear Sir, yours, \&c.

Pulborough, Dec. 16, 1839.

P. J. Martin.

XV. Notice of certain Meteorological Phonomena observed at Swansea. By J. W. G. GuTch, Esq.

To the Editors of the Philosophical Magazine and Journal. Gentlemen,

THINKING that the following notice may prove interesting to some of your meteorological readers, I forward it for insertion in your valuable publication.

On the morning of the 20th of November, an unusual rise in the barometer was observable, as sudden as it was great. At 5 p.m. on the 19 th, my barometer stood at 29.75 ; at 9 a.m. on the 20 th at 29.99 , being a rise of 0.24 . At 9 a.m. on the 21 st it sunk to $29 \cdot 99$, being a fall of $0 \cdot 70$; and so sudden a rise and fall $I$ have not had occasion to record in my registry, now kept for the last four years. The wind during the whole period was a dead calm; the weather cloudy and hazy, with occasional light showers. A similar phænomenon was observed by my friend Mr. Addison of Malvern. The sudden fall of the barometer was noticed by that gentleman on the 20th, and the rise on the 21 st, and like mine unaccompanied with wind, and at Malvern no rain fell. The explanation of this sudden rise and fall I am yet to learn, and should be glad if any of your correspondents could elucidate the subject.

On Wednesday, Nov. 6, the most brilliant meteor occurred that has been observed here for a great length of time, illu- 